\title{
Soil moisture-precipitation coupling: observations from the Oklahoma Mesonet and underlying physical mechanisms
}

\author{
T. W. Ford ${ }^{1}$, A. D. Rapp ${ }^{2}$, S. M. Quiring ${ }^{1}$, and J. Blake ${ }^{3}$ \\ ${ }^{1}$ Department of Geography, Texas A\&M University, College Station, Texas, USA \\ ${ }^{2}$ Department of Atmospheric Sciences, Texas A\&M University, College Station, Texas, USA \\ ${ }^{3}$ Department of Geology and Geophysics, Texas A\&M University, College Station, Texas, USA
}

Correspondence to: T. W. Ford (twford@tamu.edu)

Received: 5 March 2015 - Published in Hydrol. Earth Syst. Sci. Discuss.: 25 March 2015

Accepted: 31 July 2015 - Published: 21 August 2015

\begin{abstract}
Interactions between soil moisture and the atmosphere are driven by the partitioning of sensible and latent heating, through which soil moisture has been connected to atmospheric modifications that could potentially lead to the initiation of convective precipitation. The majority of previous studies linking the land surface to subsequent precipitation have used atmospheric reanalysis or model data sets. In this study, we link in situ observations of soil moisture from more than 100 stations in Oklahoma to subsequent unorganized afternoon convective precipitation. We use hourly next generation (NEXRAD) radar-derived precipitation to identify convective events, and then compare the location of precipitation initiation to underlying soil moisture anomalies in the morning. Overall we find a statistically significant preference for convective precipitation initiation over drier than normal soils, with over $70 \%$ of events initiating over soil moisture below the long-term median. The significant preference for precipitation initiation over drier than normal soils is in contrast with previous studies using satellite-based precipitation to identify the region of maximum precipitation accumulation. We evaluated 19 convective events occurring near Lamont, Oklahoma, where soundings of the atmospheric profile at 06:00 and 12:00 LST are also available. For these events, soil moisture has strong negative correlations with the level of free convection (LFC), planetary boundary layer (PBL) height, and surface temperature changes between 06:00 and 12:00 LST. We also find strong positive correlations between morning soil moisture and morning-toafternoon changes in convective available potential energy
\end{abstract}

and convective inhibition. In general, the results of this study demonstrate that both positive and negative soil moisture feedbacks are important in this region of the USA.

\section{Introduction}

\subsection{Background}

Soil moisture is vital to the climate system. Root zone soil moisture in vegetated regions has a significant influence on evapotranspiration rates (Teuling et al., 2006; McPherson, 2007) and latent and sensible heat exchange (Dirmeyer et al., 2000; Basara and Crawford, 2002; Guillod et al., 2014). Through the modification of evapotranspiration and moisture transport from the land surface to the atmosphere, soil moisture can impact regional temperature and precipitation. Because of the strong control soil moisture has on sensible and latent heating, studies have focused on the mechanistic modification of atmospheric conditions by the land surface through energy exchange. Findell and Eltahir (2003) derived a convective triggering potential and, combined with a low-level atmospheric humidity index, determined atmospheric potential for convective initiation over relatively wet or relatively dry soils in Illinois. Santanello et al. (2009) used observations of soil moisture and atmospheric conditions to describe the modification of atmospheric moisture and energy by the land surface at an hourly timescale. In addition to local-scale interactions, soil moisture-precipitation coupling can be important for mesoscale circulation initiation, particu- 
larly over strong mesoscale soil moisture heterogeneity (Taylor et al., 2011). Results from these and similar studies suggest that soil moisture anomalies, which drive preferential latent or sensible heating at the surface, can alter low-level atmospheric temperature and humidity such that atmospheric dew point depressions will be generally lower (higher) over wetter (drier) soils.

Through its control of surface evaporative fraction (EF), anomalously wet or dry soils can induce modification of the planetary boundary layer (PBL), including changes in the height of the lifting condensation level (LCL) and the level of free convection (LFC) (Brimelow et al., 2011). Without consideration of free-tropospheric conditions, afternoon LCL and LFC heights generally decrease with sufficient moisture flux from a wet soil surface, which increases energy available for convection (i.e., CAPE). In turn, relatively dry soils enhance sensible heating at the surface and promote increased LCL and LFC heights (Frye and Mote, 2010a), increasing mixed-layer stability. These mechanisms act as a positive soil moisture feedback, in which convective cloud cover and subsequent precipitation is more probable over a moist land surface than a dry land surface (Findell et al., 2011). However, studies have documented an increased probability of convective precipitation over a dry soil surface, partially attributable to dry soils (enhanced sensible heating) resulting in sufficient PBL growth and eroding of strong morning convective inhibition (CIN) (Santanello et al., 2009).

Ek and Holtslag (2004) demonstrated the interactive roles of soil moisture and free-tropospheric stability on relative humidity tendency and convective cloud development at the PBL top. Their model simulations show dry (wet) soils combined with weaker (stronger) above-PBL stability enhances the probability of PBL cloud development (Ek and Holtslag, 2004); a finding later corroborated with observations in the Sahel (Westra et al., 2012). Gentine et al. (2013) integrated the impacts of surface latent and sensible heat flux and free-tropospheric stability into a two-regime framework, specifically a wet soil advantage regime and dry soil advantage regime. Under this framework, moist convection occurs earlier over moist surfaces coinciding with strong freetropospheric stability, and occurs earlier over dry surfaces coinciding with warm, weakly stratified free-tropospheric conditions (Gentine et al., 2013). In light of the results of these studies, we could expect unorganized convection to occur over both wet and dry soils, depending on the overlying freetropospheric conditions.

Because soil moisture has a significant impact on atmospheric conditions and the persistence of strong landatmosphere interactions, it is important for seasonal climate predictions. Meng and Quiring (2010) show that anomalous spring soil moisture in the North American Great Plains influenced the amount of summer precipitation in the Community Atmosphere Model (CAM3). Roundy et al. (2013) demonstrated the importance of soil moisture conditions and land-atmosphere coupling in drought monitoring and fore- casting in the southeast USA. These and other studies suggest that land-atmosphere interactions, modulated by soil moisture, can significantly influence temperature anomalies, and potentially, precipitation, and can aid in climate and extreme event forecasting (Douville and Chauvin, 2000; Koster et al., 2011).

\subsection{Soil moisture-precipitation coupling in the US Southern Great Plains}

Although land-atmosphere interactions have considerable impact on regional climate and climate persistence, debate continues as to the sign and strength of these interactions at various scales. Global climate models have identified the US Southern Great Plains as a "hot spot" of land-atmosphere interactions wherein the probability of precipitation responds strongly to land surface conditions (Koster et al., 2004). Studies employing soil moisture observations show less consistent results, with some suggesting a wet soil advantage regime in the region (Frye and Mote, 2010b; Ford et al., 2015), and others providing evidence of a dry soil advantage regime (Santanello et al., 2013; Guillod et al., 2015). Still other studies show no evidence of soil moisture-precipitation coupling in the Southern Great Plains region, based on in situ observation (Phillips and Klein, 2014), satellite (Taylor et al., 2012), and reanalysis data sets (Findell et al., 2011). The lack of a strong, consistent land-atmosphere signal in this region is impeded by the occurrence of both positive and negative soil moisture feedbacks (Findell and Eltahir, 2003b). Additionally, the conflicting results from these and other studies are partially attributable to the breadth of data sets and methodologies employed (e.g., Findell et al., 2011; Guillod et al., 2014). However, both wet-positive and dry-negative soil moisture feedback on precipitation are potentially relevant in the Southern Great Plains.

The lack of consensus from observation-based studies on the sign and strength of soil moisture-precipitation coupling, combined with the strong positive coupling in global climate models precludes solid conclusions as to the relevance of soil moisture-precipitation coupling in the global climate system. Mesoscale studies are uniquely capable of documenting land-atmosphere interactions while simultaneously accounting for region-specific factors that could confound the results. For example, atmospheric stability in the Southern Great Plains region is significantly impacted by the strength and location of the Great Plains low-level jet (Higgins et al., 1997; Frye and Mote, 2010b). This is further complicated by the intrusion of squall lines and frontal systems during the warm season (Raddatz and Hanesiak, 2008), corresponding with conditions unfavorable for surface-induced convection (Matyas and Carelton, 2010). To properly account for these factors, we use a dense network of meteorological monitoring stations with in situ soil moisture observations, combined with radar-derived precipitation estimates and atmospheric soundings to analyze the soil moisture- 
precipitation coupling strength in the Southern Great Plains of the USA. Specifically we address whether unorganized convective events initiate preferentially over drier or wetter than normal soils in Oklahoma and document how atmospheric conditions prior to convection respond to soil moisture variability.

\section{Data and methods}

\subsection{Soil moisture data}

In situ observations of soil moisture are taken from the Oklahoma Mesonet (http://mesonet.org/), comprised of over 100 continuously monitoring stations across the state (Illston et al., 2008). Campbell Scientific 229-L heat dissipation sensors are deployed at four depths $(5,25,60,75 \mathrm{~cm})$ in the soil column and measure matric potential, from which volumetric water content is derived. Mesonet soil moisture observation error is low (Scott et al., 2013), and station density in Oklahoma is among the highest in North America.

Daily (09:00 LST) measurements are used to characterize soil moisture conditions on the morning of each convective event. Because volumetric water content is a strong function of site-specific characteristics, we convert daily volumetric water content measurements to percentiles. For this conversion, an empirical cumulative distribution function, comprised of all daily soil moisture observations for a given calendar month, is constructed. Daily observations are then fit to the distribution, and percentiles of the overall distribution are calculated. This means that a daily percentile value on, for example, 5 July of 100 represents the wettest soil moisture condition experienced during any July day over the entire study period. The percentiles are then gridded at a $0.25^{\circ}$ spatial resolution across the study region. The location of convective precipitation initiation is matched to the soil moisture grid and a corresponding soil moisture value. It is worth mentioning that soil moisture percentiles in this study represent only local temporal variability, and therefore cannot be used to examine the impact of soil moisture spatial heterogeneity on convective precipitation initiation. Soil moisture observations from the $5 \mathrm{~cm}$ depth are used in all analyses.

\subsection{Precipitation event identification}

The majority of precipitation in the central USA is caused by frontal activity and mesoscale convective systems (Raddatz and Hanesiak, 2008; Carleton et al., 2008). In these cases, moisture is advected into the region by mid-latitude cyclones or fronts (Matyas and Carleton, 2010). Therefore, analyzing the influence of soil moisture on those precipitation events will likely result in a weak or nonexistent relationship. For example, Phillips and Klein (2014) found large-scale atmospheric forcings dominated a relatively weak local feedback signal in the Southern Great Plains. Unorganized convection, as defined by Carleton et al. (2008), includes isolated convec- tive events that occur in the absence of strong, synoptic-scale atmospheric forcing. Separating these afternoon precipitation events from organized convective events, like mesoscale convective systems, and those forced by synoptic-scale atmospheric processes will help to remove confounding factors (i.e., noise) and isolate the influence of the land surface (i.e., signal).

Capturing individual convective precipitation events, particularly unorganized convection most pertinent to our study, requires data sets with a high spatial and temporal resolution. Taylor et al. (2012) identified convective events using the Climate Prediction Center morphing method (CMORPH; Joyce et al., 2004), a global precipitation data set with a $3 \mathrm{~h}$ (temporal) and $0.25^{\circ}$ (spatial) resolution. Their precipitation event detection methodology (also implemented by Ford et al., 2015 and Guillod et al., 2015) identifies the grid cell that resides within a $1.25^{\circ} \times 1.25^{\circ}$ box in which the maximum amount of precipitation occurred. It also identifies the grid cell(s) within the same $1.25^{\circ} \times 1.25^{\circ}$ box with the minimum amount of precipitation. Compositing soil moisture associated with these locations of maximum and minimum precipitation provides a means of determining whether there is a preference for convective precipitation to fall over relatively wetter or drier land surfaces. The use of CMORPH precipitation is well-suited for global-scale analyses; however, the $3 \mathrm{~h}$ temporal resolution precludes the identification of the point of precipitation initiation.

Our study identifies unorganized convective precipitation events using ground-based Doppler radar from the National Weather Surface (NWS) next generation (NEXRAD) radar network. NEXRAD includes over 160 S-band Doppler radars in the USA, including five in Oklahoma. The NWS produces their stage IV hourly precipitation product at $4 \mathrm{~km}$ spatial resolution using a mosaic of the ground-based radar data that cover nearly all of the contiguous USA (Lin and Mitchell, 2005). The stage IV product undergoes bias correction, quality control, and a series of automated algorithms and manual inspection. NEXRAD precipitation products are ideal for characterizing soil moisture-precipitation interactions occurring at sub-daily timescales (Guillod et al., 2014).

We examined hourly stage IV radar images of precipitation accumulation from 03:00 to 20:00 LST each day between May and September from 2002 to 2012, and manually identified unorganized convective events. The manual identification procedure was completed according to a predetermined decision tree (Fig. 1), which approximates the classification system of Schoen and Ashley (2011). The system of Schoen and Ashley (2011) classified storms as cellular unorganized, quasi-organized, cellular organized, and linear organized, and was based on previous studies examining radar morphology of convective storms (Parker and Johnson, 2000; Klimowski et al., 2003). The decision tree process included five assessments or queries: (1) the location of precipitation initiation, (2) minimum event size, (3) precipitation rate, (4) shape and (5) propagation of the event. The 


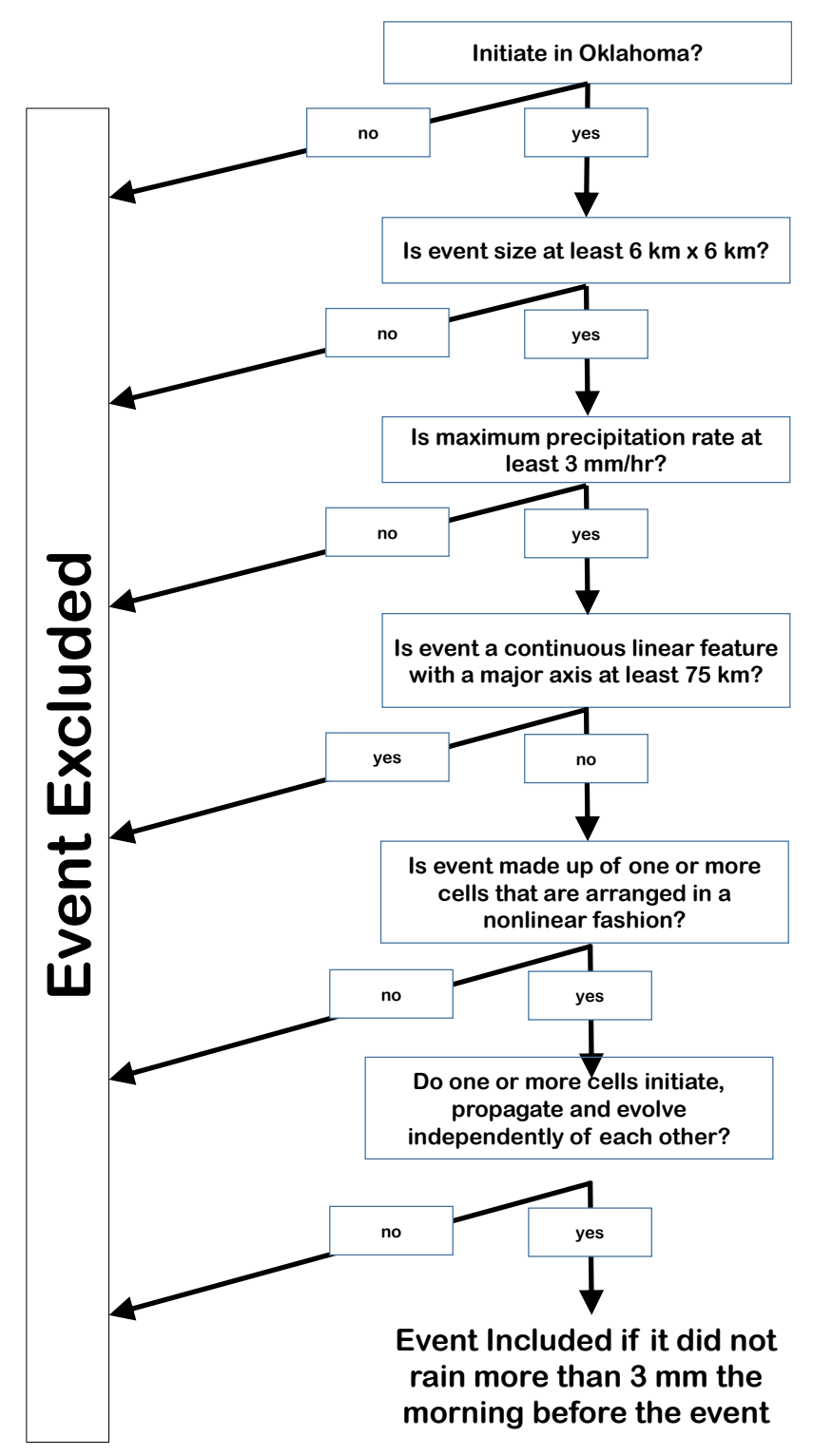

Figure 1. Schematic of the decision tree that was used for manual identification of unorganized convective events.

classification systems attempts to exclude organized convective events. Specifically, organized convective events in our classification were identified as either (1) conglomerates of convective storms arranged in a linear or quasi-linear fashion or line-echo wave pattern, including bow echoes and squall lines, or (2) as individual cells which initiate and propagate in the same vicinity and direction, arranged in a linear or nonlinear fashion (Gallus et al., 2008), and that move/evolve with respect to one another. Organized convection is undesirable because it is typically associated with the synoptic-scale atmospheric processes that we are trying to exclude from this study. The desired unorganized storm type was defined as individual cells which initiated, propagated, and evolved independently of each other and were arranged in a nonlinear fashion (Ashely and Gilson, 2009). These systems are typically shorter lived than organized events, and do not develop into or dissipate from more organized convective modes.

Manual event identification procedures have advantages and disadvantages. The primary advantage of a manual classification procedure is the ability of the researcher to discern isolated, unorganized cells from those which develop/evolve together or bifurcate from larger systems. The primary disadvantage of such a manual classification methodology is the lack of repeatability. Even with a well-rooted decision tree to guide the classification process, the results are researcherspecific. To test the reproducibility of this study, classification of all events was completed independently by two researchers. There was $72 \%$ agreement between the two researchers with regard to event identification. Agreement varied from year to year and month to month, ranging from $50 \%$ for 2009 events to $87 \%$ for 2007 events, and $63 \%$ for June events to $80 \%$ for events in September. Qualitatively, it seemed that the most frequent disagreements between researchers were for (1) multiple, isolated systems that initiated at the same time, and (2) systems which initiated in Oklahoma, but could have been associated with systems initiating outside the study region. Overall, there was a reasonable amount of consistency when using this methodology to detect unorganized convective events.

Once an unorganized convective event is identified, the location of afternoon precipitation initiation is established as the grid cell in which precipitation is first captured in the radar data set. This procedure is different from those used by Taylor et al. (2012) and Ford et al. (2015), as we identify the point of precipitation initiation instead of the region of maximum accumulation. Once the location of precipitation initiation was established for an event, we determined if more than $3 \mathrm{~mm}$ of precipitation occurred between 03:00 and 12:00 (LST) of the preceding morning within $20 \mathrm{~km}$ of the location of initiation. Convective events were retained only if precipitation did not occur or less than $3 \mathrm{~mm}$ had accumulated near the location of initiation. Through our precipitation classification methodology, 477 unorganized events were identified by both researchers during the warm season (May-September) between 2002 and 2012 in Oklahoma (Fig. 2). These events were then used to determine whether unorganized convection initiates more frequently over wetter or drier than normal soils.

\subsection{Atmospheric conditions}

In addition to documenting the frequency of convection over wet and dry soils, we also use a subset of convective events to characterize atmospheric modification by the land surface in greater detail. Soundings of the atmospheric profile allow for direct connection with the underlying land-surface conditions, but are limited in spatial coverage. Therefore, we use atmospheric soundings at 12:00 UTC (06:00 LST) and 18:00 UTC (12:00 LST) from the Department of Energy At- 


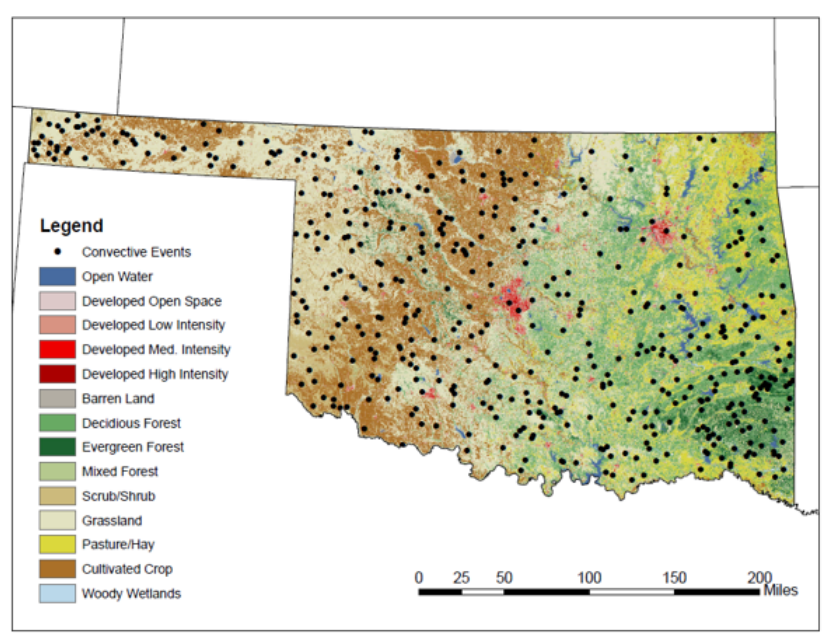

Figure 2. Location of all 477 convective events (black circles) identified between May and September form 2002 to 2012. The land cover, taken from the National Land Cover Dataset (http://www. mrlc.gov/), is also shown.

mospheric Radiation Measurement facility at Lamont, Oklahoma, for the diurnal evolution of atmospheric moisture and energy. In addition to the atmospheric soundings, we also use estimates of latent and sensible heat flux $\left(\mathrm{W} \mathrm{m}^{-2}\right)$ from the Atmospheric Radiation Measurement facility Energy Balance Bowen Ratio System at Lamont, Oklahoma. The instantaneous latent and sensible heat flux estimates at 18:00 UTC (12:00 LST) are used to calculate EF, which is the percent of incoming solar radiation used for evaporation.

Cluster analysis is used with a Ward's linkage and a fourclass maximum to separate events near Lamont. Hierarchical cluster methods, such as the Ward's method, have been used frequently for distinguishing precipitation regimes (Gong and Richman, 1995; Ramos, 2001) and other environmental patterns (Allen and Walsh, 1996). The events are clustered based on their morning (06:00 LST) convective triggering potential and low-level humidity (e.g. Findell and Eltahir, 2003). Within each cluster of events, we examine changes in atmospheric humidity and temperature, the LFC, and PBL height.

The convective environment and stability of the atmosphere associated with each precipitation event is also characterized using profile-integrated convective available potential energy (CAPE) and CIN. Taylor and Lebel (1998) suggested that soil moisture anomalies can have a significant influence on CAPE, while Myoung and NielsenGammon (2010) found a strong statistical relationship between soil moisture and CIN values in the Southern Great Plains. We calculate CAPE and CIN using the non-virtual surface parcel in this study. Atmospheric stability measures combined with changes in atmospheric humidity and temperature are linked to underlying soil moisture conditions for the events surrounding Lamont. We examine the physical mech- anisms coupling the land surface with the atmosphere, potentially leading to convective precipitation. The organization of the results and discussion are presented as follows: Sect. 3 describes the preference for convection to occur over wet or dry soils, connections between soil moisture and atmospheric conditions are presented in Sect. 4, and Sect. 5 provides a summary and discussion of our results with respect to the broader climate community.

\section{Results}

\subsection{Dry or wet soil moisture preference}

The location of precipitation initiation was identified for each precipitation event and is used to determine the soil moisture conditions in that location (grid cell). The soil moisture percentiles underlying all convective events are presented in Fig. 3. The histogram shows a larger number of convective events occurred over drier than normal soils $(<0.5)$ than over wetter than normal soils $(>0.5)$. In fact, the three lowest soil moisture bins ( $0-30$ th percentile) contain the highest number of convective events.

We evaluate the statistical significance of the preference for precipitation initiation over dry soils using a bootstrapping methodology adopted from Ford et al. (2015). The procedure compares the frequency of convective events over dry and wet soils to the frequency of dry and wet soils from of a sample of 477 randomly selected days (both event and nonevent). For the sample days, soil moisture is taken from a randomly chosen grid cell. Frequency distributions generated from the 10000 iterations of randomly sampled days are used to assess the likelihood of achieving the ratio of convective events over dry soils to those over wet soils. Based on this evaluation, the number of convective events observed to occur over drier than normal soils is associated with the 99th percentile of the bootstrapped distribution. This means that the probability of obtaining these results by chance is less than $1 \%$. Therefore, we conclude that there is a statistically significant preference for unorganized precipitation to initiate over drier than normal soils. These results suggest the presence of a dry soil advantage regime (e.g., Gentine et al., 2013) in which convective cloud development is favored over a dry soil surface with a deep PBL and a weakly stratified, warm/dry free troposphere (Huang and Margulis, 2013).

The statistically significant preference for precipitation initiation over dry soils is seemingly in direct contrast with the wet preference found in Ford et al. (2015). The primary difference between studies is the use of CMORPH for event identification by Ford et al. (2015), and NEXRAD radar in the present study. Two important advantages of NEXRAD which may be partly responsible for the contrasting results are (1) the ability to identify the location of precipitation initiation rather than the location of maximum accumulation, and (2) the ability to discern between unorganized and 


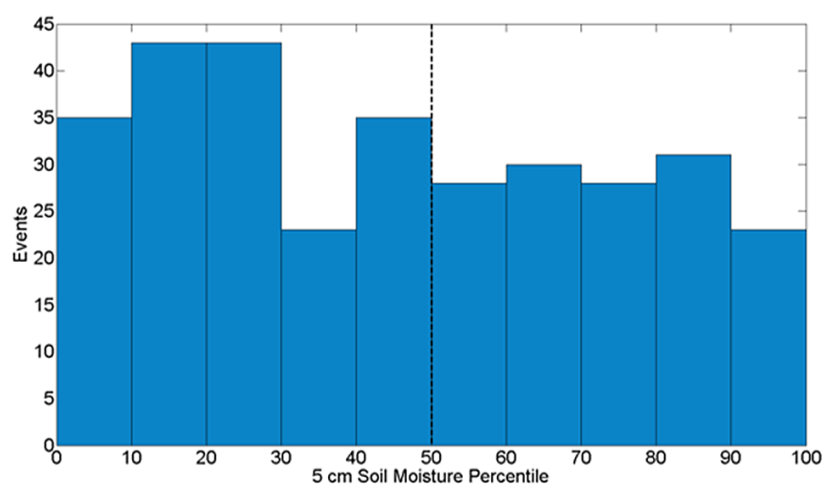

Figure 3. This figure shows the distribution of $5 \mathrm{~cm}$ soil moisture percentiles underlying all convective events identified. The dashedblack line represents the divide between relatively wet $(>50$ percentile) and relatively dry $(<50$ percentile) soils.

larger-scale organized systems (Guillod et al., 2014). For each of the 477 events, we identified both the location of precipitation initiation as well as the location of maximum precipitation accumulation. When we substitute the location of maximum accumulation for the location of initiation when compositing soil moisture underlying events, we find an even stronger preference for convection to initiate over dry soils (not shown). This suggests that the lack of agreement between the findings presented here and those in Ford et al. (2015) is most likely due to differences in the data sets and methods used to identify events. When the convective events identified in Ford et al. (2015) using methods adopted from Taylor et al. (2012) were reanalyzed, it was found that large-scale thunderstorms due to frontal activity, lowpressure systems, and even tropical storms were grouped together with mesoscale unorganized convective events (Wang et al., 2015). The ability to detect soil moisture impacts on convective precipitation initiation is hindered when events due to frontal activity and tropical storms are included because these events do not initiate over the study region. The results presented in this study, however, are based on isolating unorganized convective events and identifying the location of precipitation initiation. This gives us confidence in our assessment of the relationships between soil moisture and unorganized convective events.

\subsection{Convective event spatial variability}

Land cover and land use boundaries have been shown to dramatically impact atmospheric temperature and humidity in Oklahoma (Avissar and Pielke, 1989; McPherson et al., 2004). Therefore, we investigated whether the unorganized convective events identified in this study show any spatial patterns that are attributable to variations in land cover (Fig. 2). The G-function was used to provide a quantitative measure of spatial randomness (Diggle, 2003; Perry et al., 2006). This method examines the cumulative frequency dis-

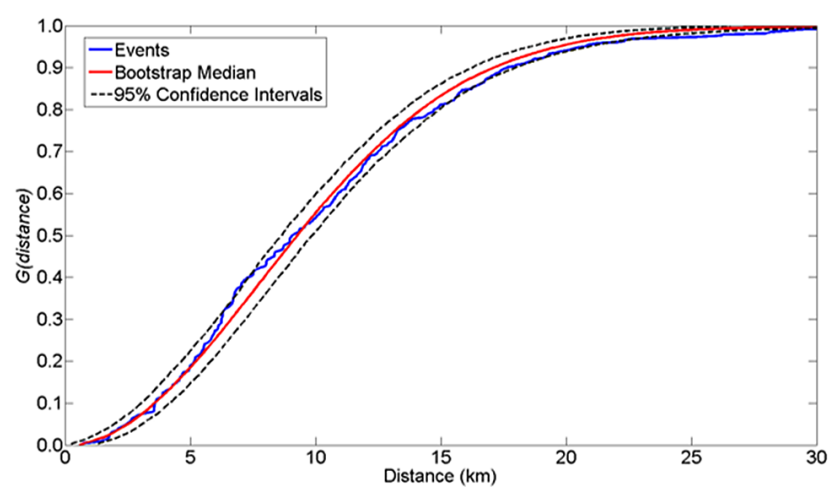

Figure 4. Cumulative distribution functions of nearest neighbor distances for all unorganized convective events (blue line), the bootstrapped median (red line) and 95\% confidence envelopes (black lines). The bootstrapped samples are calculated from 1000 iterations of 477 random events.

tribution of the nearest neighbor distances for all events. The distribution of the nearest neighbor distances calculated from the 477 convective events is then compared against the theoretical distribution of distances generated from a sample of randomly generated points that is the same size as the number of events. More specifically, 477 points are randomly placed around Oklahoma, and from these points a theoretical nearest neighbor distribution is generated. This random-point generation procedure is iterated 1000 times to create a robust theoretical distribution of the nearest neighbor distances. The 50th, 97th and 3rd percentiles are identified from this distribution and are used to represent the median and the confidence interval. The confidence interval is used to determine if the observed location of the convective events are spatially random.

Figure 4 shows the cumulative distribution functions of the nearest neighbor distances for the observed convective events (blue line), the bootstrapped median (red line), and $95 \%$ confidence envelopes (black lines). The nearest neighbor distance distribution from the convective events falls within the confidence intervals at nearly all distances and, therefore, we conclude that they are spatially random. We repeated this analysis for only wet and only dry events, and both groups were also spatially random.

Despite our findings of statistically significant spatial randomness, unorganized convective events seem to cluster in the southeast corner of the state. The cluster is coincident with predominantly mixed-forest land cover; however, no association can be made between the location of these events and land cover-induced atmospheric modification. Instead the grouping of these events is attributed to increased atmospheric instability in the form of mid-morning CAPE $\left(\mathrm{J} \mathrm{kg}^{-1}\right.$ ) (Fig. 5). Mid-morning (09:00 LST) CAPE composited for the events that occur in the southeast corner of the state (Fig. 5a) is shown separately from 09:00 LST CAPE composited for all other events (Fig. 5b). Spatial patterns of 

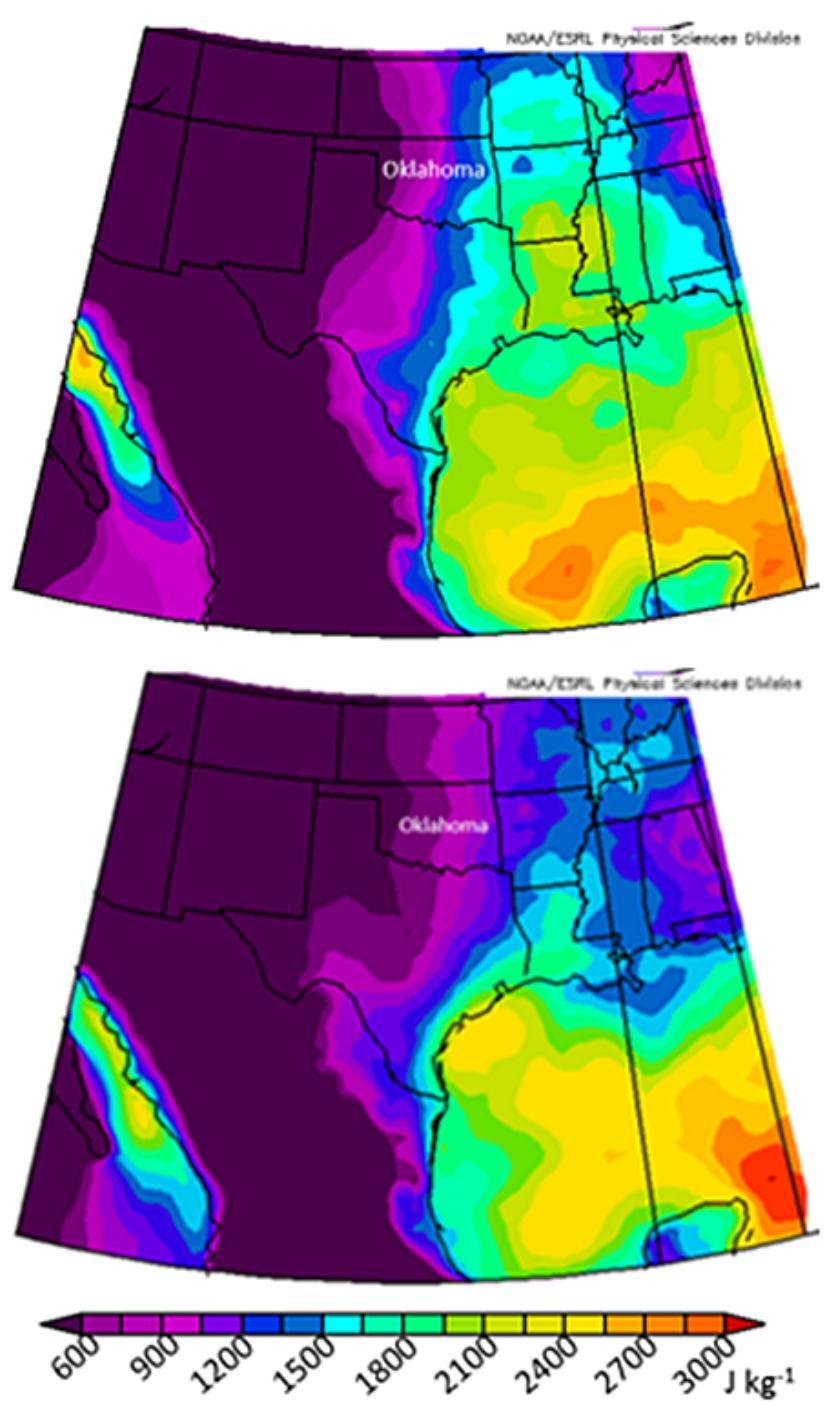

Figure 5. Composites of morning (06:00 LST) convective available potential energy from (a) events clustered in southeast corner of the study region and (b) all other convective events.

the composites are very similar, with the exception of increased CAPE in the southeast corner of the state during the clustered events. Increased potential energy and instability increases the probability of convection, and may explain the apparent grouping of events in the southeast corner of Oklahoma.

\subsection{Convective event temporal variability}

We examine the monthly and inter-annual variability of wet and dry convective events in Oklahoma. Figure 6a shows the frequency of dry and wet events during each warm season between 2002 and 2012, as well as total (May-September) precipitation $(\mathrm{mm})$ for each year, averaged over all Oklahoma climate divisions. Precipitation totals are taken from the National Climate Data Center Climate Divisional Dataset
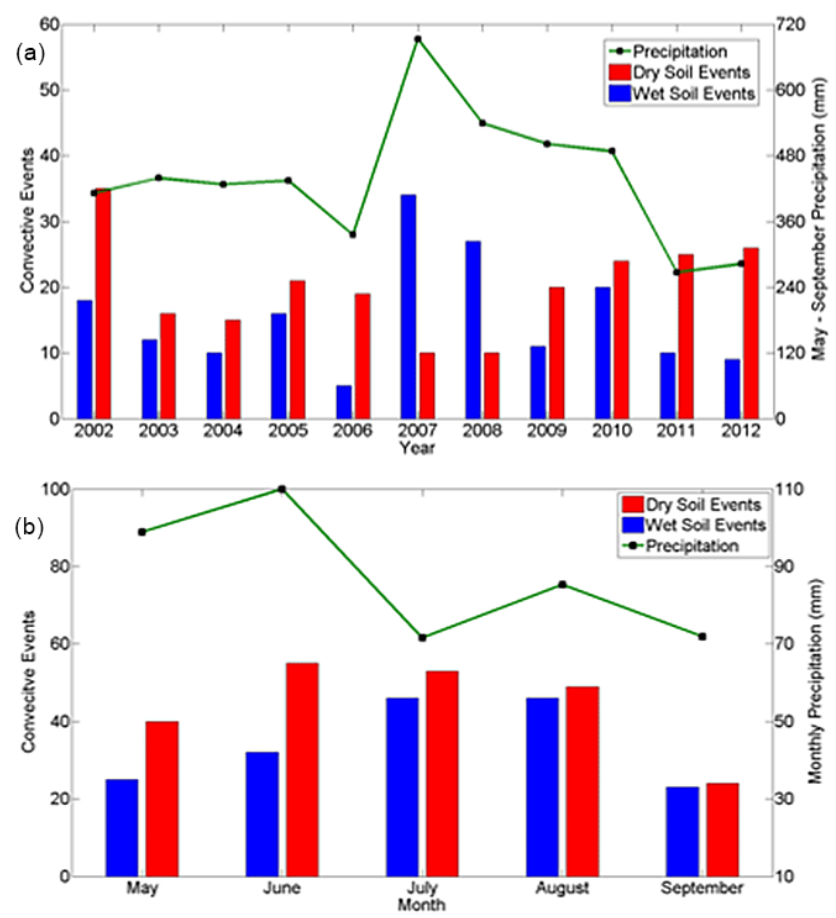

Figure 6. Top panel (a) shows the frequency of dry and wet events during each warm season between 2002 and 2012, as well as the total May-September precipitation $(\mathrm{mm})$ for each year. The bottom panel (b) shows the monthly variability of all events, color coded into dry and wet categories, as well as average (2002-2012) monthly precipitation $(\mathrm{mm})$.

(http://www.ncdc.noaa.gov/cag/). The ratio of dry soil events to wet soil events closely follows the total (May-September) precipitation each year. The 2 years, 2007 and 2008, with more wet soil events than dry soil events experienced the wettest and second wettest seasons over the study period, at 693 and $539 \mathrm{~mm}$, respectively. The years with the highest dry soil to wet soil event ratios $(2002,2006,2011,2012)$ had the four lowest seasonal precipitation totals. The fact that wet soil events tend to occur in wet years and dry soil events tend to occur in dry years is expected because of the direct impact precipitation has on soil moisture, irrespective of any soil moisture feedback. In addition, because our study focuses on the location of convective precipitation initiation, we cannot account for the potential influence of atmospheric persistence and the impact of large-scale atmospheric conditions (e.g., Taylor et al., 2011). Therefore, it is important to note that the patterns shown in Fig. 6 might simply depict the impact of precipitation on soil moisture, rather than a wet or dry soil feedback.

Interestingly, the total number of events per year does not seem to be connected to the seasonal precipitation totals. A similar number of events occurred in 2011 (28), a very dry year, as in 2008 (29), which was a wet year. However, the lack of correspondence between total seasonal precipi- 

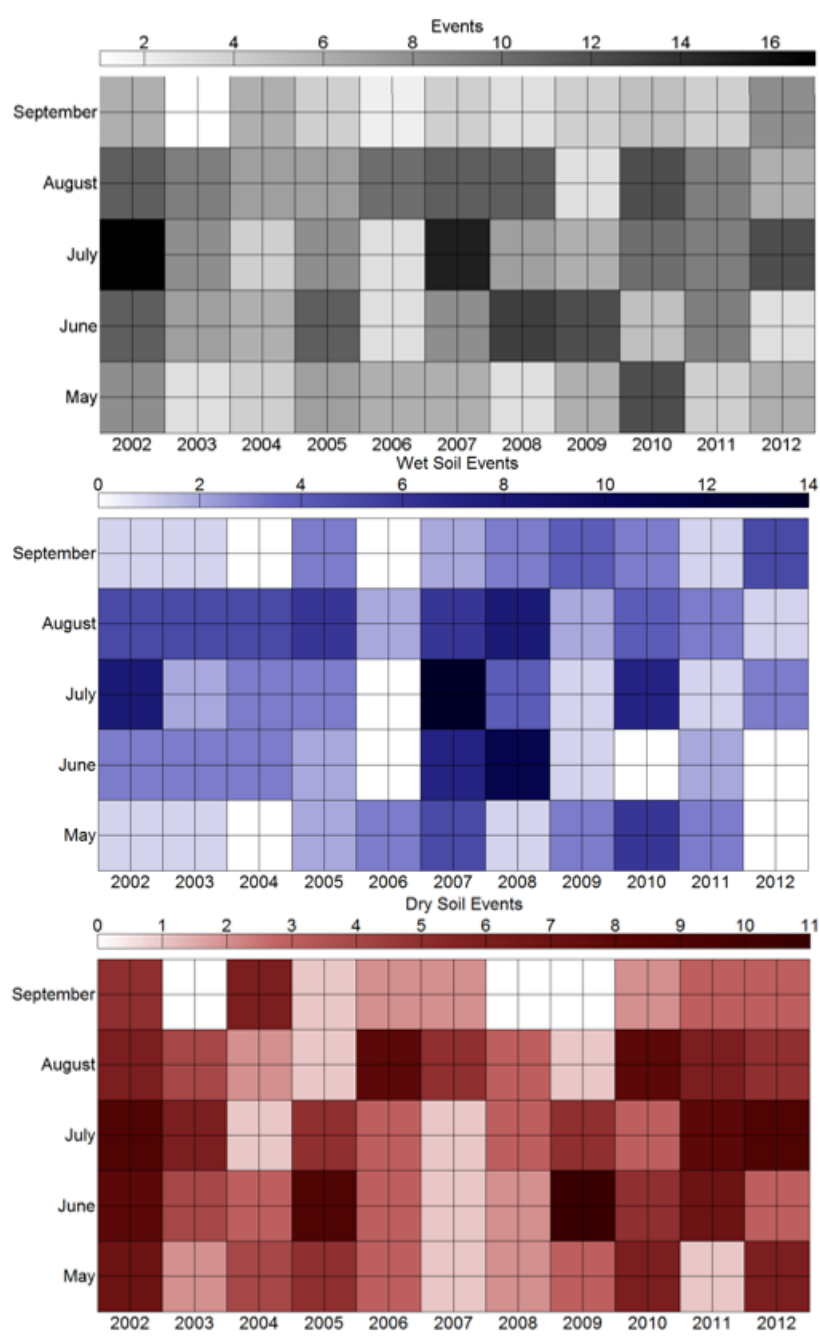

Figure 7. Frequency of unorganized convective events in each month during the 2002-2012 study period. The top panel represents all events, the middle panel is the wet events and the bottom panel is the dry events.

tation and the number of convective events could be due to our preferential selection of unorganized convective events. Figure $6 \mathrm{~b}$ shows the monthly variability of all unorganized convective events, both dry and wet. Dry events occur more frequently in May and June than July and August, when the number of wet events increases. To better describe the patterns of temporal variability shown in Fig. 6, we combine monthly and annual frequency into one grid (Fig. 7). The top panel in Fig. 7 shows the frequency of all events, while the middle and bottom panels show frequencies of wet and dry events, respectively. The primary conclusion that can be drawn from Fig. 7a is that the unorganized convective events tend to occur most frequently between June and August, coinciding with the peak convective season in the Southern Great Plains (Fritsch et al., 1986). While Fig. 7a is divided somewhat horizontally between the middle and be- ginning/end of the warm season, Fig. $7 b$ and $c$ are split vertically. The frequency of wet events (Fig. 7b) is relatively consistent from year to year between 2002 and 2006, with August exhibiting the most frequent wet events. This pattern changes in 2007 and 2008, with a considerable increase in wet event frequency for nearly all months, except September and May. These 2 very wet years are followed by a pattern that is similar to that observed during 2002 to 2006. The increase in wet events in 2007 and 2008 corresponds with a simultaneous decrease in dry events during the same time period. The warm season in 2007 was the second wettest on record in Oklahoma, with total precipitation more than $237 \mathrm{~mm}$ above the 30 -year mean. Although the same time period in 2008 was less anomalous (25th wettest on record), precipitation was still more than $75 \mathrm{~mm}$ above the mean. The abundant precipitation during these two warm seasons led to near-saturated soils for the majority of the time and helps to explain why convection initiated preferentially over wetter than normal soils (i.e., atmospheric persistence, Taylor et al., 2011).

Over the 11-year study there is, on average, a statistically significant preference for precipitation to initiate over drier than normal soils. However, the total number of events and ratio of dry to wet soil events varies considerably on inter-annual and monthly timescales. Wet soil events occurred most frequently in August during years with less-thannormal to normal precipitation. Not surprisingly, seasons with dry and near-normal rainfall conditions coincided with a higher dry to wet event ratio, while convection over wet soils was most frequent during seasons with above-normal precipitation totals.

\subsection{Atmospheric pre-conditioning to convection}

This study has produced a climatology of unorganized convection in Oklahoma and connected the location of initiation with soil moisture conditions. This analysis is useful for improving our understanding of the relationship between soil moisture and the location and timing of convection. In this section we investigate the physical mechanisms that link the land surface and atmosphere. We composited convective events occurring within $50 \mathrm{~km}$ of Lamont, Oklahoma, where atmospheric soundings are taken daily at 06:00 and 12:00 LST. These events were used to quantify the relationship between the land surface and the atmosphere. The $50 \mathrm{~km}$ threshold was selected based on the expected representativeness of the atmospheric profile (Potvin et al., 2010) over Lamont as well as the spatial autocorrelation of soil moisture in Oklahoma. Convective events were only retained if (1) they occurred within $50 \mathrm{~km}$ of Lamont, (2) afternoon precipitation was also recorded in Lamont, or (3) soil moisture percentiles in the grid cell where convection occurred had the same anomaly (wet or dry) as Lamont. Based on these criteria, 19 events were selected for analysis. 
The goal of this analysis is to document the differences in atmospheric conditions between 06:00 and 12:00 LST preceding convection and to account for atmospheric preconditioning to convection occurring over wet soils and that occurring over dry soils. We used convective triggering potential (CTP; $\left.\mathrm{J} \mathrm{kg}^{-1}\right)$ and low-level humidity $\left(\mathrm{HI}_{\mathrm{low}} ;{ }^{\circ} \mathrm{C}\right)$, adopted from Findell and Eltahir (2003a), to identify events with a morning atmosphere pre-conditioned for convection over wet soils, dry soils, or convection regardless of the land surface. CTP is the integrated area between the environmental temperature profile and a moist adiabat from 900 to $700 \mathrm{mb}$. The $\mathrm{HI}_{\text {low }}$ is the summation of the dew point depression at 950 and $850 \mathrm{mb}$. The atmospheric levels used for these calculations are taken directly from Findell and Eltahir (2003a) and are assumed to be relevant for Oklahoma.

This comparison is important, as morning atmospheric conditions from which dry soils could potentially force convection should be very different than those favoring wetsoil-forced convection. Namely, a dry soil surface modifies atmospheric conditions by forcing PBL growth and freetropospheric air entrainment, while wet soils effect specific humidity within the PBL (Gentine et al., 2013). Preference for afternoon convective cloud development over wet or dry soils will depend on morning PBL depth and the stability, temperature, and moisture of free-tropospheric air (Findell and Eltahir, 2003a; Huang and Margulis, 2011). Therefore, morning (06:00 LST) atmospheric profiles and CTP-HI low conditions over dry and wet soils are expected to be noticeably different. Figure 8 a shows all 19 events composited around Lamont, plotted in dual CTP-HI ter plot shows clear separation of the dry and wet soil events, particularly in the vertical $\left(\mathrm{HI}_{\text {low }}\right)$ and to a lesser extent in the horizontal (CTP). Atmospheric conditions prior to convection over wet soils are characterized by an environmental temperature profile relatively close to the moist adiabatic lapse rate, with an average CTP of $139 \mathrm{~J} \mathrm{~kg}^{-1}$ and high humidity at low levels (mean $\mathrm{HI}_{\text {low }}$ of $10^{\circ} \mathrm{C}$ ). These conditions are similar to the findings of Findell and Eltahir (2003a) for deep convection initiating over wet soils, and are consistent with a wet soil advantage regime (Gentine et al., 2013) in which the wet soils impact PBL-specific humidity and therefore PBL depth (i.e., dynamic factor). Atmospheric conditions prior to convection over dry soils have much higher CTP values (mean of $313 \mathrm{~J} \mathrm{~kg}^{-1}$ ) and higher $\mathrm{HI}_{\text {low }}$ (mean of $25^{\circ} \mathrm{C}$ ), representing less stability of the free troposphere (Huang and Margulis, 2011). Delineation of morning atmospheric conditions between wet and dry soil convective events (Fig. 8a) is remarkably consistent with wet and dry soil advantage regimes reported by Gentine et al. (2013), representing the importance of both surface soil moisture conditions and pre-convective atmospheric thermal stability in determining a wet or dry soil preference (Huang and Margulis, 2011).

In addition to the separation of dry and wet events in CTP$\mathrm{HI}_{\text {low }}$ space, there appears to be a distinction within dry and
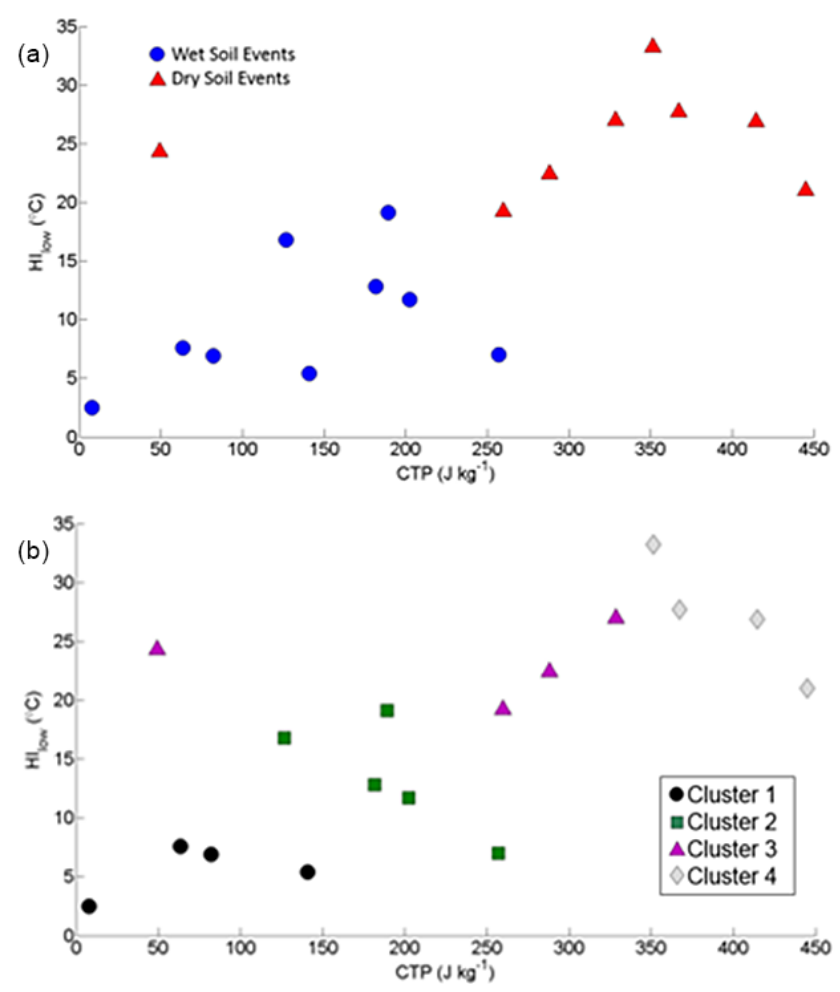

Figure 8. Scatter plots of the 19 unorganized convective events that occurred near Lamont, OK, in dual (06:00 LST) convective triggering potential $\left(\mathrm{J} \mathrm{kg}^{-1}\right)$ - humidity index $\left({ }^{\circ} \mathrm{C}\right)$ space: (a) wet events are denoted by the blue circle and dry events are denoted by a red triangle. (b) Events are grouped into four clusters.

wet events (Fig. 8a). We clustered the 19 events using the 06:00 LST CTP and $\mathrm{HI}_{\mathrm{low}}$ and a hierarchical clustering algorithm with the Ward's linkage and a four-class maximum. Clustering has been shown to be a useful method for distinguishing disparate conditions leading to the different scatter points (Khong et al., 2015), and is therefore deemed appropriate here. The result of the clustering is shown in Fig. 8b, which displays a similar scatter plot as Fig. 8a, only with points separated into distinct clusters. The four clusters span the entire CTP-HI $\mathrm{H}_{\text {low }}$ range and increase in both CTP and $\mathrm{HI}_{\text {low }}$, generally from cluster 1 to cluster 4 . Interestingly, despite not including soil moisture as a variable for the clustering analysis, the algorithm divided wet events (clusters 1 and 2) from dry events (clusters 3 and 4). The clusters are used to demonstrate the 06:00 to 12:00 LST atmospheric modification in terms of underlying soil moisture and the preconditioning of the morning atmosphere to convection over wet or dry soils. 
Table 1. Mean atmospheric conditions at 06:00 and 12:00 LST from atmospheric soundings, averaged by event cluster. Conditions summarized include convective available potential energy $\left(\mathrm{J} \mathrm{kg}^{-1}\right)$, convective inhibition $\left(\mathrm{J} \mathrm{kg}^{-1}\right)$, the level of free convection (mb), convective temperature $(\mathrm{C})$, and the height of the planetary boundary layer $(\mathrm{m})$. Mean convective event duration (h), size (pixels), and precipitation accumulation $(\mathrm{mm})$ are composited by cluster as well.

\begin{tabular}{lrrrr}
\hline Cluster & 1 & 2 & 3 & 4 \\
\hline Soil moisture $($ percentile $)$ & 0.74 & 0.65 & 0.18 & 0.10 \\
CAPE-12Z $\left(\mathrm{J} \mathrm{kg}^{-1}\right)$ & 1634.50 & 686.60 & 366.75 & 96.50 \\
CAPE-18Z $\left(\mathrm{J} \mathrm{kg}^{-1}\right)$ & 2522.50 & 1133.00 & 485.00 & 231.00 \\
CIN-12Z $\left(\mathrm{J} \mathrm{kg}^{-1}\right)$ & 144.70 & 190.20 & 324.00 & 426.50 \\
CIN-18Z $\left.(\mathrm{J} \mathrm{kg})^{-1}\right)$ & 48.12 & 57.60 & 88.75 & 94.75 \\
LFC-12Z $(\mathrm{mb})$ & 717.50 & 730.20 & 649.75 & 594.75 \\
LFC-18Z $(\mathrm{mb})$ & 822.25 & 764.60 & 656.75 & 626.25 \\
ConvTemp-12Z $\left({ }^{\circ} \mathrm{C}\right)$ & 27.00 & 26.40 & 35.50 & 40.25 \\
PBL-12Z (m) & 305.26 & 438.98 & 370.02 & 629.00 \\
PBL-18Z (m) & 743.70 & 1788.28 & 2173.84 & 3128.63 \\
Event duration (h) & 4.25 & 3.25 & 3.75 & 2.75 \\
Event size (pixels) & 23.00 & 10.75 & 18.5 & 7.25 \\
\hline Total event accumulation $(\mathrm{mm})$ & 1748.05 & 395.97 & 546.40 & 77.66 \\
\hline
\end{tabular}

\subsection{Physical connections between soil moisture and atmospheric conditions}

Atmospheric profiles from soundings at 06:00 and 12:00 LST are used to characterize conditions and modification from the morning to afternoon before convection occurs. At both 06:00 and 12:00 LST, we calculate the LFC (mb), PBL height $(\mathrm{m})$, and surface temperature $\left({ }^{\circ} \mathrm{C}\right)$. Additionally for the 06:00 LST sounding, we calculate convective temperature $\left({ }^{\circ} \mathrm{C}\right)$, the temperature the near-surface must reach for convection to occur in the absence of synoptic forcing mechanisms, to represent the potential for convection given adequate surface heating. We also calculate CAPE and CIN $\left(\mathrm{J} \mathrm{kg}^{-1}\right)$ to characterize atmospheric stability at both sounding times. Large differences are observed between the clusters for all atmospheric measures. Table 1 shows the average LFC height, CAPE, CIN, convective temperature, and PBL height from 06:00 to 12:00 LST as well as the average 09:00 LST soil moisture percentile for events in each cluster. CAPE (CIN) values are much higher (lower) at both 06:00 and 12:00 LST for clusters 1 and 2 events, corresponding with relatively wet soils. Additionally, these clusters have relatively lower LFC and PBL heights and much lower 06:00 LST convective temperatures. In direct contrast, dry soil events in clusters 3 and 4 are characterized by relatively low (high) CAPE (CIN) values, deeper PBLs and higher LFC heights. However, more interesting than atmospheric conditions at any one point during the day, are the modifications of atmospheric conditions between 06:00 and 12:00 LST.

Figure 9 shows scatter plots of the soil moisture percentiles and the 12:00-06:00 LST difference in (a) LFC height (mb), (b) PBL height (m), and (c) surface temperature $\left({ }^{\circ} \mathrm{C}\right)$, delineated by cluster. Additionally, Fig. 9d shows the same scat- ter plot, only with 06:00 LST convective temperature on the $y$ axis. The drier soils of clusters 3 and 4 correspond to increased LFC height, stronger PBL growth and increased surface air temperature and morning convective temperature. The change in these atmospheric conditions is an ideal example of the thermodynamic effect for a deep boundary layer over strong surface sensible heating, with decreased LCL and LFC height compared to PBL growth (Santanello et al., 2011; Gentine et al., 2013). In contrast, events from wet soil events of clusters 1 and 2 show limited PBL growth, decreased LFC heights, lower convective temperature, and smaller changes in surface temperature from 06:00 to 12:00 LST. This is characteristic of a stable PBL moistened by increased latent heating from a relatively wet surface (i.e., dynamic effect, Gentine et al., 2013). Despite the small sample size, all of the relationships depicted in Fig. 9 are statistically significant. The coefficients of determination for soil moisture and changes in LFC height, PBL height, surface temperature, and convective temperature are $0.26,0.49,0.60$, and 0.53 , respectively. Obviously the relationship between soil moisture and near-surface atmospheric temperature is strongest; however, even with varying atmospheric conditions from 19 events, soil moisture percentiles at 09:00 LST still explain more than $25 \%$ of the variance in LFC height change from 06:00 to 12:00 LST.

Along with changes in the atmospheric temperature and LFC/PBL heights, we also relate soil moisture percentiles from the 19 events to atmospheric stability. Figure 10a shows scatter plots of soil moisture percentile and the change (difference) in CAPE ( $\triangle \mathrm{CAPE}, \mathrm{J} \mathrm{kg}^{-1}$ ) between 12:00 and 06:00 LST. Figure 10b shows the same scatter plot, only showing the 12:00-06:00 LST difference in CIN $\left(\Delta \mathrm{CIN}, \mathrm{J} \mathrm{kg}^{-1}\right.$ ) delineated by cluster. For clarity, negative 

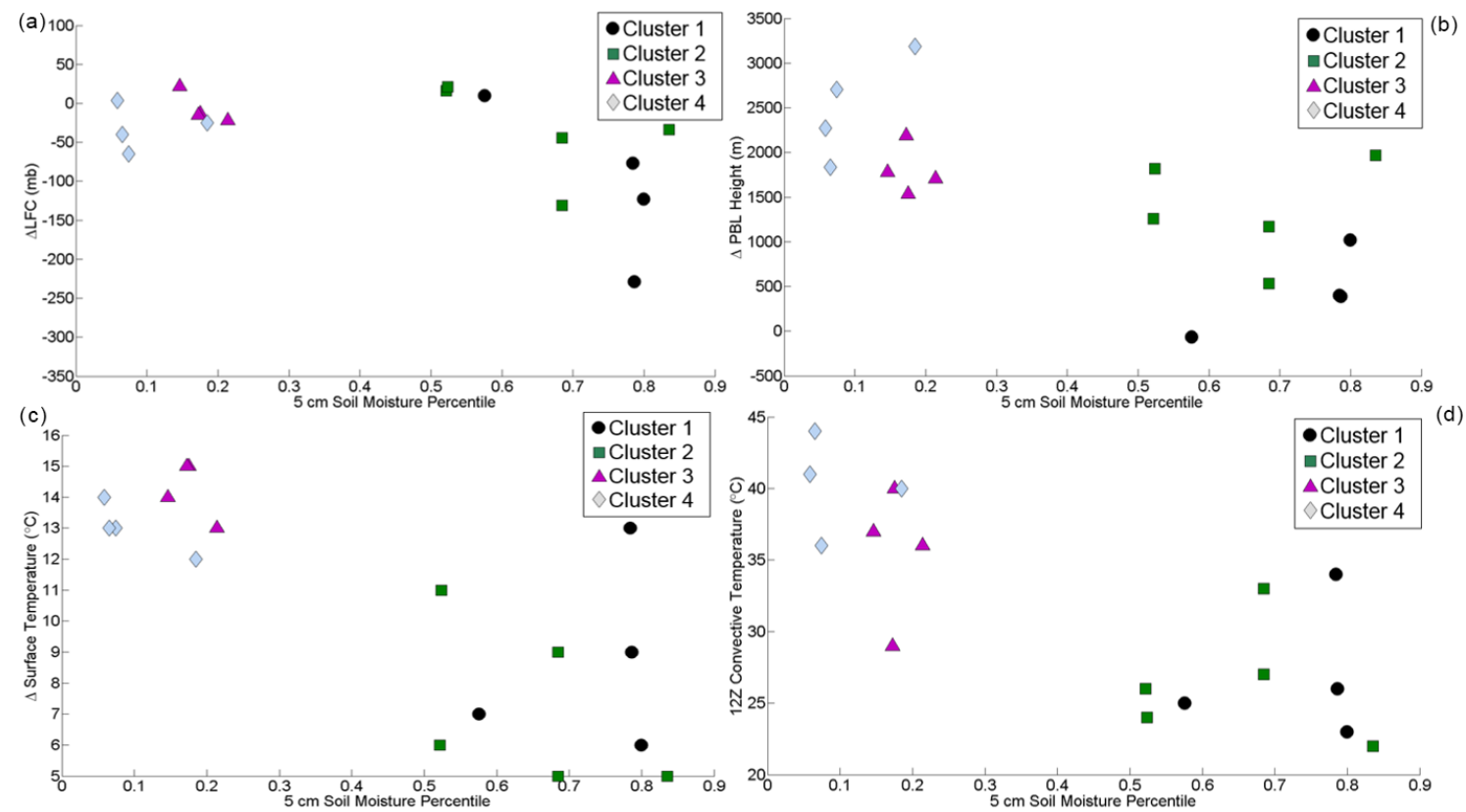

Figure 9. Scatter plots of soil moisture percentiles and atmospheric conditions of 19 unorganized convective events that occurred near Lamont, OK: (a) soil moisture percentiles versus changes in LFC height, (b) soil moisture percentiles versus changes in PBL height, (c) soil moisture percentiles versus surface temperature, and (d) soil moisture percentiles versus 12:00 UTC convective temperature.
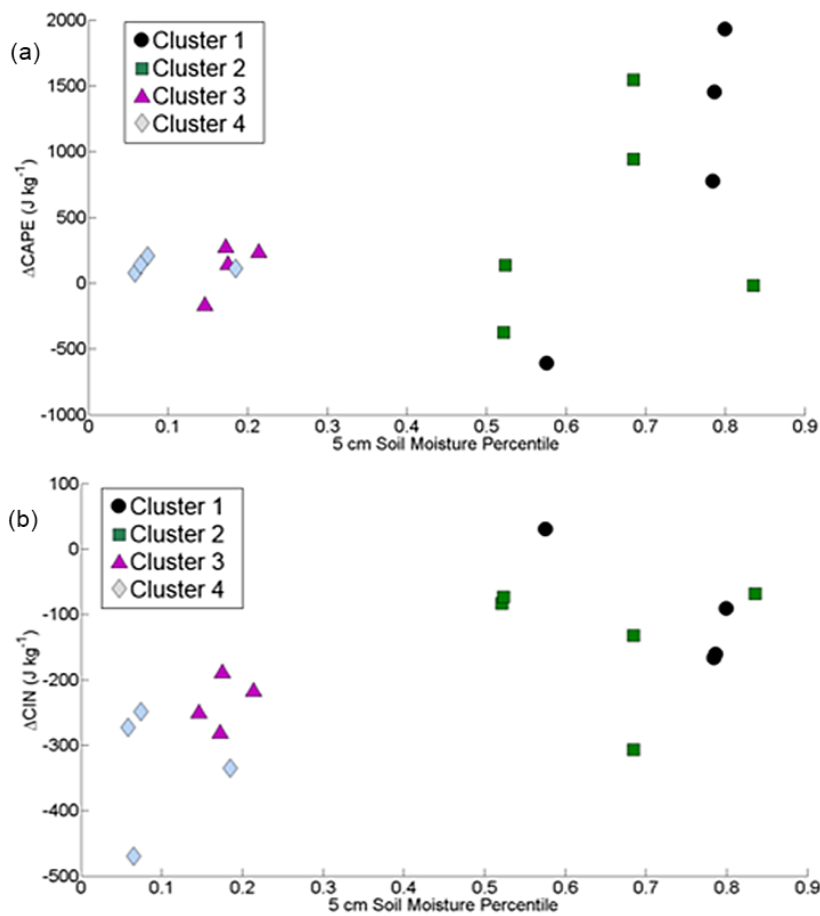

Figure 10. Scatter plots of soil moisture percentiles and (a) the change in convective available potential energy and (b) the change in convective inhibition between 06:00 and 12:00 LST. Events shown here occur within $50 \mathrm{~km}$ of Lamont, Oklahoma. $\triangle \mathrm{CIN}$ values represent a decrease in CIN (decrease in stability) between 06:00 and 12:00 LST. The general relationship between soil moisture and the changes in both CAPE and CIN are positive, with (wet soil) events in clusters 1 and 2 corresponding with larger (smaller) changes in CAPE (CIN). Mechanistically, drier than normal soils enhance sensible heating at the surface, which results in increased nearsurface air temperature and heating of the air parcel near the surface (Fig. 9c). The enhanced warming of the surface allows the surface temperature to approach (or to reach) the convective temperature, essentially decreasing CIN values. Wet soils diminish surface heating, which results in a negligible change in CIN between 06:00 and 12:00 LST. Concurrently, wetter than normal soils provide enhanced moisture flux to the atmosphere through increased latent heating (Ek and Holtslag, 2004; Gentine et al., 2013). This decreases the level of the LFC (Fig. 9a) and increases CAPE throughout the profile. Through the modification of CAPE and CIN, both wet and dry soils have the potential to initiate convection, and in the case of our 19 events, are physically linked to modifications of the atmosphere. The coupling between soil moisture and CAPE/CIN is also statistically significant, with coefficient of determination values of 0.42 and 0.77 , respectively. This means that an overwhelming amount of variance in the evolution of CIN between 06:00 and 12:00 LST (77\%) is captured by 09:00 LST soil moisture percentiles.

Gentine et al. (2013) delineated positive and negative regions of relative humidity sensitivity to $\mathrm{EF}$, through which convection is induced. We examine our 17 convective events 

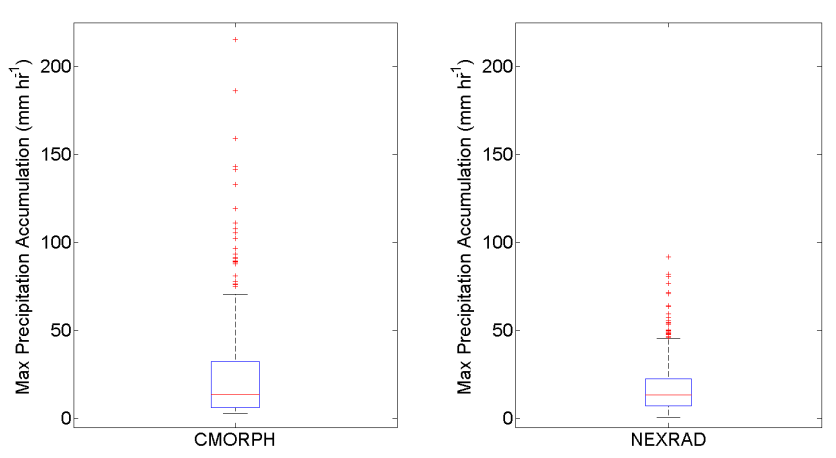

Figure 11. Maximum precipitation accumulation rates $\left(\mathrm{mm} \mathrm{h}^{-1}\right)$ composited from (left panel) 353 events identified by Ford et al. (2015) using CMORPH and (right panel) 477 events identified in this study with NEXRAD.

in $(12: 00 \mathrm{LST})$ potential temperature slope $\left(\gamma_{\theta}, \mathrm{K} \mathrm{km}^{-1}\right)-\mathrm{EF}$ space to determine if we can similarly separate the events into regions of positive and negative relative humidity sensitivity (Fig. 12). Although not as distinct as the separation demonstrated by Gentine et al. (2013), the 17 convective events show a delineation along $\gamma_{\theta}$-EF space. Mixed-layer relative humidity is most sensitive to changes in surface energy flux when evaporation is constrained under a less stable boundary layer and when evaporation is enhanced under a more stratified boundary layer. The convective events are colored in Fig. 12 based on the $5 \mathrm{~cm}$ soil moisture percentile underlying the initiation point. Event separation is further demonstrated as wet and dry soil advantage regimes (e.g., Gentine et al., 2013), corresponding with positive and negative regions of relative humidity sensitivity, respectively. Overall, the pattern shown in Fig. 12 supports the dual wet soil/dry soil advantage regimes proposed by Gentine et al. (2013), and suggest that convective initiation can occur under both regimes in the Southern Great Plains.

Through the manual event identification procedure, we were able to quantify individual event duration (hours), average size (pixels), and total precipitation accumulation ( $\mathrm{mm}$ ) (Table 1). We relate these event characteristics to precedent land surface and atmospheric conditions using correlation analysis. All three event characteristics (duration, size, total precipitation) are significantly, negatively related to the change in PBL height $(\mathrm{m})$ between 06:00 and 12:00 LST. Larger PBL growth (over predominantly drier soils) corresponds with decreased atmospheric relative humidity, which results in events with shorter duration, smaller size, and less overall precipitation. The coefficient of determination between the change in PBL height and duration, size, and total precipitation are $0.22,0.31$ and 0.40 , respectively. Two of the three characteristics, duration and total precipitation, are significantly, positively related to CAPE at 06:00 LST. Events exhibiting larger CAPE values correspond to longer event duration and more total precipitation, with coefficient of determination values of 0.41 and 0.85 , respectively. The

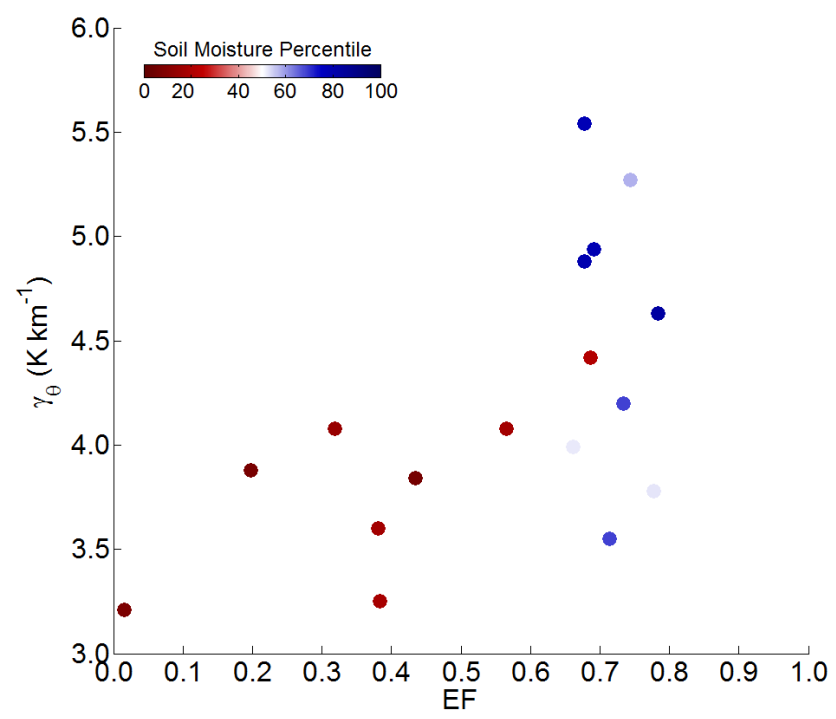

Figure 12. Convective events over Lamont, Oklahoma, in terms of 12:00 LST atmospheric stability $\left(\gamma_{\theta}\right)$, and surface evaporative fraction. The scatter points are colored based on the $5 \mathrm{~cm}$ soil moisture percentile underlying each convective event.

soil moisture percentile does not have a statistically significant relationship with any of the event characteristics.

\section{Summary and conclusions}

Soil moisture-precipitation interactions have been a major avenue of hydroclimatic research for decades. Previous studies have found evidence of a wet-positive soil moisture feedback in which increased latent heating from a wet soil surface moistens a stable PBL, decreasing surface temperatures, the lifting condensation level, and the level of free convection, and increasing CAPE (Pielke, 2001; Pal and Eltahir, 2001; Ek and Holtslag, 2004; Ferguson and Wood, 2011; Huang and Margulis, 2011). In contrast, other studies have found that anomalously dry soils can impact convective initiation more strongly than wet soils through increased sensible heat flux, a decrease in CIN, and increase in PBL height (Santanello et al., 2009; Taylor et al., 2012). The preference for convective development over relatively dry soils is particularly evident when PBL growth entrains relatively warm, dry air from a weakly stratified free-troposphere (Westra et al., 2012; Gentine et al., 2013).

Our results show a statistically significant preference for unorganized convection to occur over drier than normal soils, although there are a non-negligible number of events that occur over wet soils. Importantly, the ability of our analysis to discern between unorganized convection and organized systems associated with frontal passage and low-pressure systems is dependent on our precipitation event identification. Automated event identification algorithms using other data sets, such as CMORPH, tend to lump together unor- 
ganized convective events (e.g., those initiating from localscale processes), with large-scale frontal systems and tropical storms that do not initiate over the region of interest (Wang et al., 2015). We compare maximum hourly precipitation accumulation between the 477 events identified here using NEXRAD and the 353 events identified in Ford et al. (2015) using CMORPH (Fig. 11). The CMORPH events have a significantly larger median maximum hourly accumulation rate, as determined using the Kruskill-Wallis test, than the NEXRAD events. However, the largest differences between the data sets are in the right tail of the distribution, with many CMORPH event accumulation rates exceeding $100 \mathrm{~mm} \mathrm{~h}^{-1}$. The occurrence of extremely large precipitation rates in the CMORPH data set suggests that events associated with large-scale systems are being included in the 353 events. Therefore, the lack of agreement between the results of this study and previous studies (Taylor et al., 2012; Ford et al., 2015) can be partly attributed to the different data products and methods used for event identification. With these results in mind, we argue that our manual event identification procedure works best for (1) identifying the point of precipitation initiation and (2) separating unorganized from organized convective events. Therefore, we have confidence in our assessment of the relationships between soil moisture and unorganized convective events.

After compositing 19 events near Lamont, OK, where atmospheric soundings observations were available, we found strong connections between soil moisture and atmospheric modification between 06:00 and 12:00 LST. The strongest modification was to CIN and surface air temperature during this time period, as soil moisture explained 77 and $60 \%$ of the variance, respectively. Soil moisture has been previously connected to changes in near-surface air temperature in Oklahoma, albeit at much longer timescales (Ford and Quiring, 2014). Basara and Crawford (2002) also found that the daily evolution of the PBL, including $2 \mathrm{~m}$ air temperature, was connected to soil moisture anomalies on clear-sky days. The strong connection between soil moisture and CIN is mechanistically consistent with enhanced (diminished) surface heating over dry (wet) soils. Myoung and NielsenGammon (2010) showed that on monthly timescales, CIN was a better determinant to the occurrence of precipitation during the warm season in Texas. However, their results also showed a strong, negative relationship between soil moisture and CIN such that drier than normal soils resulted in stronger CIN values and therefore stronger atmospheric stability (Myoung and Nielsen-Gammon, 2010). The results from our analysis are not necessarily in disagreement because we evaluated the relationship between soil moisture and the 06:00 to 12:00 LST change in CIN. In fact, as Table 1 shows, 06:00 and 12:00 LST CIN values were strongest over dry soils; however, the enhanced surface heating attributable to moisture-limited land surface conditions in these cases allowed for more rapid surface heating and therefore a larger overall decrease in CIN over dry soils. It should be noted that although stronger CIN over drier than normal soils (e.g., Myoung and Nielsen-Gammon, 2010) can be considered a general deterrent for convection, dry soils can also erode strong CIN much more quickly than wetter soils due to increased sensible heating.

The results of this study show strong statistical relationships between soil moisture and several atmospheric conditions and stability indices. These relationships are mechanistically consistent with wet-positive and dry-negative feedbacks to precipitation, suggesting that both positive and negative soil moisture feedbacks are relevant in this region of the USA.

Acknowledgements. We gratefully acknowledge the National Science Foundation (award numbers: AGS-1056796, BCS-1433881) for funding this work. We would also like to thank the Oklahoma Mesonet for providing soil moisture observations used in this work. Data files from the Mesonet can be obtained online at http: //www.mesonet.org/index.php/weather/category/past_data_files. Finally, we would like to thank Pierre Gentine and an anonymous reviewer for their helpful comments and suggestions.

Edited by: P. Gentine

\section{References}

Allen, T. R. and Walsh, S. J.: Spatial and compositional pattern of alpine treeline, Glacier National Park, Montana, Photogram. Eng. Rem. Sens., 62, 1261-1268, 1996.

Ashley, W. S. and Gilson, C. W.: A reassessment of U.S. lightning mortality, B. Am. Meteorol. Soc., 90, 1501-1518, doi:10.1175/2009BAMS2765.1, 2009.

Avissar, R. and Pielke, R. A.: A parameterization of heterogeneous land surfaces for atmospheric numerical models and its impact on regional meteorology, Mon. Weather Rev., 117, 2113-2136, doi:10.1175/1520-0493, 1989.

Basara, J. B. and Crawford, K. C.: Linear relationships between root-zone soil moisture and atmospheric processes in the PBL, J. Geophys. Res., 107, ACL 10-1-ACL 10-18, doi:10.1029/2001JD000633, 2002.

Brimelow, J. C., Hanesiak, J. M., and Burrows, W. R.: Impacts of land-atmosphere feedbacks on deep, moist convection on the Canadian Prairies, Earth Interact., 15, 1-29, doi:10.1175/2011EI407.1, 2011.

Carleton, A. M., Arnold, D. L., Travis, D. J., Curran, S., and Adegoke, J. O.: Synoptic circulation and land surface influences on convection in the Midwest US "Corn Belt" during the summers of 1999 and 2000. Part I: Composite synoptic environments, J. Climate, 21, 3389-3415, doi:10.1175/2007JCLI1578.1, 2008.

Diggle, P. J., Ribeiro, P. J., and Christensen, O.: An introduction to model-based geostatistics, in: Spatial statistics and computational methods. Lecture Notes in Statistics 173, edited by: Møller, J., Springer, New York, 43-86, 2003.

Dirmeyer, P. A., Zeng, F. J., Ducharne, A., Morrill, J. C., and Koster, R. D.: The sensitivity of surface fluxes to soil water content in three land surface schemes, J. Hydrometeorol., 1, 121-134, 
doi:10.1175/1525-7541(2000)001<0121:TSOSFT>2.0.CO;2, 2000.

Douville, H. and Chauvin, F.: Relevance of soil moisture for seasonal climate predictions: a preliminary study, Clim. Dynam., 16, 719-736, doi:10.1007/s003820000080, 2000.

Ek, M. B. and Holtslag, A. A. M.: Influence of soil moisture on boundary layer cloud development, J. Hydrometeorol., 5, 86-99, doi:10.1175/1525-7541, 2004.

Ferguson, C. R. and Wood, E. F.: Observed land-atmosphere coupling from satellite remote sensing and reanalysis, J. Hydrometeorol., 12, 1221-1254, doi:10.1175/2011JHM1380.1, 2011.

Findell, K. L. and Eltahir, E. A. B.: Atmospheric controls on soil moisture-boundary layer interactions. Part I: Framework development, J. Hydrometeorol., 4, 552-569, doi:10.1175/15257541(2003)004<0552:ACOSML>2.0.CO;2, 2003a.

Findell, K. L. and Eltahir, E. A. B.: Atmospheric controls on soil moisture-boundary layer interactions. Part II: Feedbacks within the Continental United States, J. Hydrometeorol., 4, 570-583, $2003 b$.

Findell, K. L., Gentine, P., Lintner, B. R., and Kerr, C.: Probability of afternoon precipitation in eastern United States and Mexico enhanced by high evaporation, Nature, 4, 434-439, doi:10.1038/ngeo1174, 2011

Ford, T. W. and Quiring, S. M.: In situ soil moisture coupled with extreme temperatures: A study based on the Oklahoma Mesonet, Geophys. Res. Lett., 41, 4727-4734, doi:10.1002/2014GL060949, 2014.

Ford, T. W., Rapp, A. D., and Quiring, S. M.: Does afternoon precipitation occur preferentially over dry or wet soils in Oklahoma?, J. Hydrometeorol., 16, 874-888, doi:101.1175/JHM-D-14-0005.1, 2015.

Fritsch, J. M., Kane, R. J., and Chelius, C. R.: The contribution of mesoscale convective weather systems to the warm-season precipitation in the United States, J. Appl. Meteorol. Clim., 25, 1333-1345, doi:10.1175/15200450(1986)025<1333:TCOMCW>2.0.CO;2, 1986.

Frye, J. D. and Mote, T. L.: Convection initiation along soil moisture boundaries in the southern Great Plains, Mon. Weather Rev., 138, 1140-1151, doi:10.1175/2009MWR2865.1, 2010a.

Frye, J. D. and Mote, T. L.: The synergistic relationship between soil moisture and the low-level jet and its role on the prestorm environment in the Southern Great Plaisn, J. Appl. Meteorol. Clim., 49, 775-791, doi:10.1175/2009JAMC2146.1, $2010 \mathrm{~b}$.

Gallus Jr., W. A., Snook, N. A., and Johnson, E. V.: Spring and summer severe weather reports over the Midwest as a function of convective mode: A preliminary study, Weather Forecast., 23, 101-113, doi:10.1175/2007WAF2006120.1, 2008.

Gentine, P., Holtslag, A. A. M., D’Andrea, F., and Ek, M.: Surface and atmospheric controls on the onset of moist convection over land, J. Hydrometeorol., 14, 1443-1462, doi:10.1175/JHMD-12-0137.1, 2013.

Gong, X. and Richman, M. B.: On the application of cluster analysis to growing season precipitation data in North America East of the Rockies, J. Climate, 8, 897-931, doi:10.1175/15200442(1995)008<0897:OTAOCA>2.0.CO;2, 1995.

Guillod, B. P., Orlowsky, B., Miralles, D., Teuling, A. J., Blanken, P. D., Buchmann, N., Ciais, P., Ek, M., Findell, K. L., Gentine, P., Lintner, B. R., Scott, R. L., Van den Hurk, B., and I. Seneviratne, S.: Land-surface controls on afternoon precipitation diagnosed from observational data: uncertainties and confounding factors, Atmos. Chem. Phys., 14, 8343-8367, doi:10.5194/acp-14-83432014, 2014.

Guillod, B. P., Orlowsky, B., Miralles, D. G., Teuling, A. J., and Seneviratne, S. I.: Reconciling spatial and temporal soil moisture effects on afternoon rainfall, Nature, 6, 6443, doi:10.1038/ncomms7443, 2015.

Higgins, R. W., Yao, Y., Yarosh, E. S., Janowiak, J. E., and Mo, K. C.: Influence of the Great Plains Low-Level Jet on summertime precipitation and moisture transport over the Central United States, J. Climate, 10, 481-507, doi:10.1175/1520-0042, 1997.

Huang, H. and Margulis, S. A.: Impact of soil moisture heterogeneity length scales and gradients on daytime coupled land-cloudy boundary layer interactions, Hydrol. Process., 27, 1988-2003, doi:10.1002/hyp.9351, 2013.

Illston, B. G., Basara, J. B., Fiebrich, C. A., Crawford, K. C., Hunt, E., Fisher, D. K., Elliott, R., and Humes, K.: Mesoscale monitoring of soil moisture across a statewide network, J. Atmos. Ocean. Tech., 25, 167-182, doi:10.1175/2007JTECHA993.1, 2008.

Joyce, R. J., Janowiak, J. E., Arkin, P. A., and Xie, P.: CMORPH: A method that produces global precipitation estimates from passive microwave and infrared data at high spatial and temporal resolution, J. Hydrometeorol., 5, 487-503, doi:10.1175/15257541(2004)005<0487:CAMTPG>2.0.CO;2, 2004.

Khong, A., Wang, J. K., Quiring, S. M., and Ford, T. W.: Soil moisture variability in Iowa, Int. J. Climatol., 35, 2837-2848, doi:10.1002/joc.4176, 2015.

Klimowski, B. A., Bunkers, M. J., Hjelmfelt, M. R., and Covert, J. N.: Severe convective windstorms over the Northern High Plains of the United States, Weather Forecast., 18, 502-519, doi:10.1175/1520-0434(2003)18<502:SCWOTN>2.0.CO;2, 2003.

Koster, R. D., Dirmeyer, P. A., Guo, Z., Bonan, G., Chan, E., Cox, P., Gordon, C. T., Kanae, S., Kowlczyk, E., Lawrence, D., Liu, P., Lu, C., Malyshev, S., McAvaney, B., Mitchell, K., Mocko, D., Oki, T., Oleson, K., Pitman, A., Sud, Y. C., Taylor, C. M., Verseghy, D., Vasic, R., Xue, Y., and Yamada, T.: Regions of strong coupling between soil moisture and precipitation, Science, 305, 1138-1140, doi:10.1126/science.1100217, 2004.

Koster, R. D., Mahanama, S. P. P., Yamada, T. J., Balsamo, G., Berg, A. A., Boisserie, M., Dirmeyer, P. A., Doblas-Reyes, F. J., Drewitt, G., Gordon, C. T., Guo, Z., Jeong, J. H., Lee, W. S., Li, Z., Luo, L., Malyshev, S., Merrfield, W. J., Senevirantne, S. I., Stanelle, T., van den Hurk, B. J. J. M., Vitart, F., and Wood, E. F.: The second phase of the Global LandAtmosphere Coupling Experiment: soil moisture contributions to subseasonal forecast skill, J. Hydrometeorol., 12, 805-822, doi:10.1175/2011JHM1365.1, 2011.

Lin, Y. and Mitchell, K. E.: The NCEP Stage II/IV hourly precipitation analyses: development and applications, 19th Conf. on Hydrology, American Meteorological Society, Paper 1.2, 9-13 January 2005, San Diego, CA, 2005.

Matyas, C. J. and Carleton, A. M.: Surface radar-derived convective rainfall associations with Midwest US land surface conditions in summer seasons 1999 and 2000, Theor. Appl. Clim., 99, 315330, doi:10.1007/s00704-009-0144-7, 2010.

McPherson, R. A.: A review of vegetation-atmosphere interactions and their influences on mesoscale phenomena, Prog. Phys. Geogr., 31, 261-285, doi:10.1177/0309133307079055, 2007. 
McPherson, R. A., Stensrud, D. J., and Crawford, K. C.: The impact of Oklahoma's winter wheat belt on the mesoscale environment, Mon. Weather Rev., 132, 405-421, doi:10.1175/15200493, 2004.

Meng, L. and Quiring, S. M.: Examining the influence of spring soil moisture anomalies on summer precipitation in the U.S. Great Plains using the Community Atmosphere Model version 3, J. Geophys. Res., 115, D21118, doi:10.1029/2010JD014449, 2010.

Myoung, B. and Nielsen-Gammon, J. W.: The convective instability pathway to warm season drought in Texas. Part I: The role of convective inhibition and its modulation by soil moisture, J. Climate, 23, 4461-4473, doi:10.1175/2010JCLI2946.1, 2010.

Pal, J. S. and Eltahir, E. A. B.: Pathways relating soil moisture conditions to future summer rainfall within a model of the land-atmosphere system, J. Climate, 14, 1227-1242, doi:10.1175/1520-0442(2001)014<1227:PRSMCT>2.0.CO;2, 2001.

Parker, M. D. and Johnson, R. H.: Organizational models of midlatitude mesoscale convective systems, Mon. Weather Rev., 128, 3413-3436, doi:10.1175/15200493(2001)129<3413:OMOMMC>2.0.CO;2, 2001.

Perry, G. L. W., Miller, B. P., and Enright, N. J.: A comparison of methods for the statistical analysis of spatial point patterns in plant ecology, Plant. Ecol., 187, 59-82, doi:10.1007/s11258006-9133-4, 2006.

Phillips, T. J. and Klein, S. A.: Land-atmosphere coupling manifested in warm-season observations on the U.S. southern great plains, J. Geophys. Res., 119, 509-528, doi:10.1002/2013JD020492, 2014.

Pielke, R. A.: Influence of the spatial distribution of vegetation and soils on the prediction of cumulus convective rainfall, Rev. Geophys., 39, 151-177, doi:10.1029/1999RG000072, 2001.

Potvin, C. K., Elmore, K. L., and Weiss, S. J.: Assessing the impacts of proximity sounding criteria on the climatology of significant tornado environments, Weather Forecast., 25, 921-930, doi:10.1175/2010WAF2222368.1, 2010.

Raddatz, R. L. and Hanesiak, J. M.: Significant summer rainfall in the Canadian Prairie Provinces: modes and mechanisms 20002004, Int. J. Climatol., 28, 1607-1613, doi:10.1002/joc.1670, 2008.

Ramos, M. C.: Divisive and hierarchical clustering techniques to analyse variability of rainfall distribution patterns in a Mediterranean region, Atmos. Res., 57, 123-138, doi:10.1016/S01698095(01)00065-5, 2001

Roundy, J. K., Ferguson, C. R., and Wood, E. F.: Temporal variability of land-atmosphere coupling and its implications for drought over the Southeast United States, J. Hydrometeorol., 14, 622635, doi:10.1175/JHM-D-12-090.1, 2013.
Santanello, J. A., Peters-Lidard, C. D., Kumar, S. V., Alonge, C., and Tao, W.: A modeling and observational framework for diagnosing local land-atmosphere coupling on diurnal time scales, J. Hydrometeorol., 10, 577-599, doi:10.1175/2009JHM1066.1, 2009.

Santanello, J. A., Peters-Lidard, C. D., and Kumar, S. V.: Diagnosing the sensitivity of local land-atmosphere coupling via the soil moisture-boundary layer interaction, J. Hydrometeorol., 12, 766-786, doi:10.1175/JHM-D-10-05014.1, 2011.

Santanello, J. A., Peters-Lidard, C. D., Kennedy, A., and Kumar, S. V.: Diagnosing the nature of land-atmosphere coupling: A case study of dry/wet extremes in the U.S. Southern Great Plains, J. Hydrometeorol., 14, 3-24, doi:10.1175/JHM-D-12-023.1, 2013.

Schoen, J. M. and Ashley, W. S.: A climatology of fatal convective wind events by storm type, Weather Forecast., 26, 109-121, doi:10.1175/2010WAF2222428.1, 2011

Scott, B. L., Ochsner, T. E., Illston, B. G., Fiebrich, C. A., Basara, J. B., and Sutherland, A. J.: New soil property database improves Oklahoma Mesonet soil moisture estimates, J. Atmos. Ocean. Tech., 30, 2585-2595, doi:10.1175/15200493(2001)129<3413:OMOMMC>2.0.CO;2, 2013.

Taylor, C. M. and Lebel, T.: Observational evidence of persistent convective-scale rainfall patterns, Mon. Weather Rev., 126, 1597-1607, doi:10.1175/15200493(1998)126<1597:OEOPCS>2.0.CO;2., 1998.

Taylor, C. M., Gounou, A., Guichard, F., Harris, P. P., Ellis, R. J., Couvreux, F., and De Kauwe, M.: Frequency of Sahelian storm initiation enhanced over mesoscale soil-moisture patterns, Nature, 4, 430-433, doi:10.1038/ngeo1173, 2011.

Taylor, C. M., de Jeu, R. A., Guichard, F., Harris, P. P., and Dorigo, W. A.: Afternoon rain more likely over drier soils, Nature, 489, 423-426, doi:10.1038/nature11377, 2012.

Teuling, A. J., Seneviratne, S. I., Williams, C., and Troch, P. A.: Observed timescales of evapotranspiration response to soil moisture, Geophys. Res. Lett., 33, L23403, doi:10.1029/2006GL028178, 2006.

Wang, J. K., Ford, T. W., and Quiring, S. M.: Distinguishing between unorganized and organized convection when examining land-atmosphere relationships, J. Appl. Meteorol. Clim., in review, 2015.

Westra, D., Steeneveld, G. J., and Holtslag, A. A. M.: Some observational evidence for dry soils supporting enhanced relative humidity at the convective boundary layer top, J. Hydrometeorol., 13, 1347-1358, doi:10.1175/JHM-D-11-0136.1, 2012. 